\title{
Determinants in implementing a public policy for an essential volume of free water in Bogotá and Medellín, Colombia
}

\author{
Determinantes da implementação da política pública de um \\ volume essencial de água gratuita em Bogotá e Medellín, Colômbia
}

Laura Vargas ${ }^{1}$

Léo Heller ${ }^{2}$
${ }^{1}$ Departamento de Engenharia Sanitária e Ambiental, Universidade Federal de Minas Gerais. Av. Antônio Carlos 6627, Pampulha. 31270-901 Belo Horizonte MG Brasil. vargaslauramarcela@ gmail.com

${ }^{2}$ Centro de Pesquisas René Rachou, Fiocruz. Belo

Horizonte MG Brasil.

\begin{abstract}
Within the framework for the realization of the human right to water and sanitation, States have the obligation to implement programs and public policies that satisfy the basic needs of their population, especially its most vulnerable demographics. In Colombia, this challenge has been addressed through policies that provide a determined essential amount of free water to people whose access to water and sanitation services are limited due to low income. Through a review of legal and technical documents as well as relevant literature, this article presents an analysis of the particular determinants involved in implementing this program in Bogotá and Medellin, as well as some related concerns. Among such factors, we discuss the evolution and changes of the tariff model used in service provision, estimates of basic consumption, the role of social movements and collective action, and user disconnection due to non-payment. The main particularities and differences of each case highlighted the inconveniences related to the method of identifying eligible users and applying assistance to beneficiary user groups, and the need for national guidelines in implementing this policy.

Key words Water, Sanitation, Affordability, $\mathrm{Hu}$ man right, Essential minimum
\end{abstract}

Resumo No marco da realização do direito humano à água e ao esgotamento sanitário os Estados têm a responsabilidade de implementar programas e politicas públicas que visam a satisfazer as necessidades essenciais da população, especialmente a mais vulnerável. Na Colômbia tem se abordado esse desafio mediante politicas que garantam o acesso em um volume vital, gratuito, para a população cuja capacidade de pagamento é limitada para ter acesso ao serviço de agua e esgotamento sanitário. Através de uma análise de conteúdo, baseado na legislação, documentos técnicos e revisão de literatura, nesse artigo se analisam os determinantes da implementação dessa medida em Bogotá e Medellín e suas particularidades, assim como se apontam algumas preocupações relacionadas. Entre os condicionantes se consideram a evolução e as mudanças do regime tarifário para a prestação do serviço, as estimativas dos consumos básicos, o papel dos movimentos sociais e da ação coletiva, e a desconexão pela incapacidade de pagamento dos usuários. A partir de cada caso e de suas principais diferenças foi possivel evidenciar, entre outros inconvenientes, os relacionados com o método de identificação da população beneficiada e a necessidade de pautas a nível nacional para a implementação dessa política.

Palavras-chave Água, Esgotamento sanitário, Acessibilidade econômica, Direito humano, Mínimo essencial 


\section{Introduction}

Improving access to water and sanitation has strong short-term and long-term positive effects on a country's economic growth and on the portions of its population in conditions of poverty. Appropriate service provision is key to reducing the risk of water-related diseases, as well as satisfying needs for drinking water, food preparation, and personal and domestic hygiene $e^{1,2}$.

In General Comment $n^{\circ} 15$ of the Committee on Economic, Social and Cultural Rights (CESCR), a United Nations (UN) treaty body, the definition of the human right to water "entitles everyone to sufficient, safe, acceptable, physically accessible and affordable water for personal and domestic uses", and gives all implicated State Members' governments the duty to realise this human right. Moreover, the UN General Assembly officially recognised the human right to water and sanitation in 2010 in Resolution 64/292.

One of the conditions that hinders people's access to water and sanitation is tied to their specific socio-economic situation; people living in extreme poverty are still largely excluded from these services. In general, subsidies made available by States only reach those within areas with service coverage and with already existing personal connections ${ }^{3}$.

Having a connection to a collective piped water and basic sanitation network does not guarantee that one will have access to water. Limitations exist such as the price of the service, since water is supplied under market conditions that make access dependent upon the user's ability to pay, which can hinder access to this essential good $^{4,5}$. Consequently, users can opt to remain disconnected from the system and fall back on informal connections or water sources, oblivious to the associated risks.

Equity and non-discrimination are cross-cutting human rights principles that governments must live up to by guaranteeing both opportunities and outcomes, regardless of people's social conditions. Governments must also recognise people's difficulties and needs, offering assistance and support when necessary ${ }^{6}$. Vertical equity is a concept in which differential treatment must exist for users with different socioeconomic statuses, meaning in accordance with their ability to pay ${ }^{7}$.

One strategy in this line of thought is the implementation of public policies that take non-regressive charges into consideration through differential billing rates or compensatory measures for vulnerable parts of the population. This alter- native presents the challenge of finding balance to governments and service providers, between making services affordable for the poor, applying a reasonable tariff that will favour the rational use of water ${ }^{4}$, and also maintaining the economic sustainability of services ${ }^{8}$.

The present article will analyse the main technical, social, political and economic aspects that led to the implementation of the Minimum Essential Potable Water (Minimo Vital de Agua Potable - MVAP) program and its variations in Bogotá and Medellín (Figure 1). The purpose of the program is to provide families in conditions of poverty with a minimum essential amount of free water through the cities' piped water and sanitation services.

Among cases of cities practicing forms of free water provision, the case of South Africa has been the most recognized. Other notable cases have occurred in Chile and Uruguay, in cities such as New Delhi and Barcelona, and Belgium's Flemish Region. These cases differ in the minimal quantity of free water that is supplied and eligibility conditions required to receive this benefit.

Despite the fact that providing an essential minimum amount of free water thereby attempts

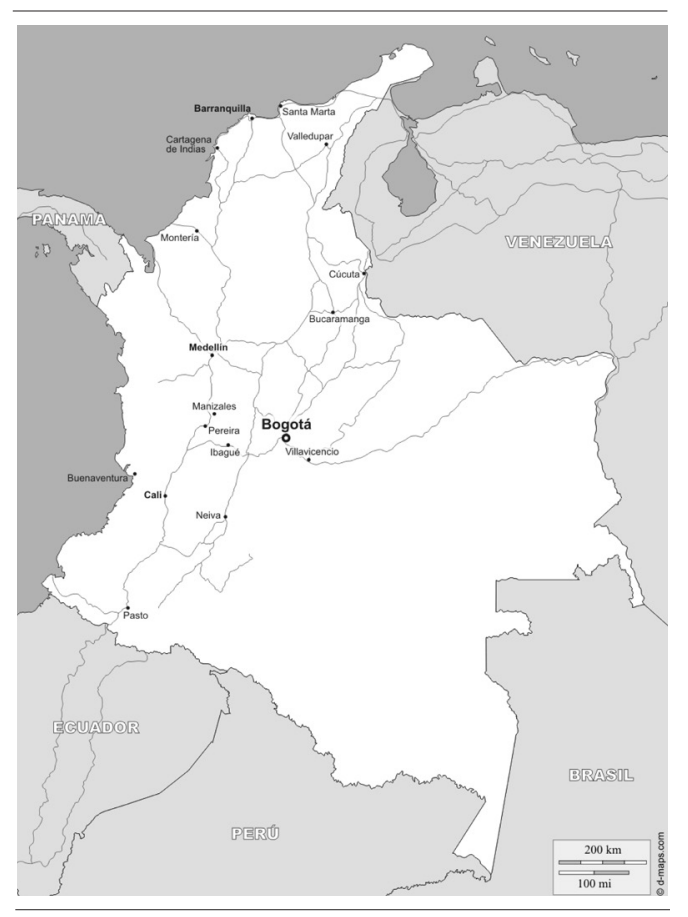

Figure 1. Cities of Colombia map.

Source: http://www.d-maps.com/ 
to realise the human right to water in terms of its affordability, the outcomes do not always match the intentions. The program's implementation conditions could leave out those most disadvantaged or could assist others that do not need the subsidy. In this regard, it appears pertinent to analyse the following two cases and to recognise their differences, the preoccupations and inconveniences regarding each of the respective implementation models' characteristics and circumstances. This is especially relevant since a national-scale public policy does not exist on this subject and some cities in Colombia have already demonstrated their interest in replicating these programs.

The present analysis used the method of content analysis and was based mainly on the review of Colombia's current legislation concerning the provision of water and sanitation services. This review also included studies and technical documents that were created or commissioned by the public companies responsible for service provision, or developed by academic institutions in the scope of national-scale research. Additionally, a literature review was also performed in order to nourish and complement the discussion of the national-scale findings.

This article is divided into four sections including the present introduction. The second section describes and analyses the determinants that led to the initiative of providing a minimum essential amount of free water in both cities. The third section details the characteristics of the implementation model adopted by each city, identifies their differences and elucidates their possible inconveniences. The conclusion will discuss the final and most important considerations.

\section{Main determinants regarding the implementation of the minimum essential potable water program in Colombia}

\section{The water and sanitation service provision} regime, fees and subsidies

In Colombia, the changes throughout history in management models for water and sanitation service provision have been stimulated by continuous inefficiencies in coverage, continuity and quality, caused by problems in resource administration and the absence of sources of financing in this sector. Billing regimes had an important role in past crises. As a result of politicised management, they presented considerable weaknesses and were determined by each service provider without guidelines or effective regulation, which was reflected by their low rates and, thus, inefficiency in service and coverage?

The National Tariff Board (Junta Nacional de Tarifas) was a regulatory entity that was created in 1968 with the purpose of establishing tariffs taking into consideration economic costs, subsidies and economic efficiency. It was thus that the tariff structure based itself on property appraisals with the supposition that this criteria would reflect the inhabitants' ability to pay ${ }^{9}$. However, this mechanism presented great problems in terms of inconsistencies due to a lack of updated data, and from 1983 onward was replaced by that of socioeconomic stratification'.

Furthermore, tariffs were determined based on consumption ${ }^{10}$, under the premise that the latter would increase for users with greater incomes and, thus, that services would be rendered less expensive for users with low consumption. This became a general subsidy that benefited the vast majority of users with ability to pay and low consumption, and negatively impacted users with little income and large families. Therefore, what appeared to be a positive measure in the short term became regressive over time, since it led to the impossibility of improving and expanding services due to service providing companies' (SPC) financial instability 9

The government granted supply-side subsidies, paying part of the costs for expansions with transfers and public resources 9 . These subsidies varied considerably and could be as much $90 \%$ of costs for the 1st, 2nd and 3rd strata, while contributors paid as much as $20 \%$ of the cost over$\operatorname{run}^{11}$.

Due to these difficulties, in 1991 the Political Constitution of Colombia recognised the relevance of residential public services based on three facts: the significant, direct relationship between access to public services and the population's quality of life and health; the need for efficient public services for competitive productivity in the market; and the great investment required for service provision.

Consequently, the Constitution establishes access to potable water as a social objective of the State. It defines that the State must create solutions for unsatisfied essential needs, and may grant subsidies to parts of the population with little income within certain limits.

It is thus that Law 142 of 1994 was passed, which created the Residential Public Services Board (RPSB) in light of the above-mentioned inefficiencies in service provision. The Board aimed to expand coverage, incorporate the par- 
ticipation of private companies, separate the responsibilities of the State from those of the SPCs, guarantee citizen participation and establish a more balanced regime for tariffs and subsidies than that which had previously been in place ${ }^{12}$. As concerns the latter goal, a system applying socioeconomic stratification was formally established which classified dwellings into 6 strata based on the characteristics of their place of residence and their environing conditions, the first of which representing those most socio-economically disadvantaged.

Thus, the corresponding local entities created the Solidarity and Income Redistribution Funds (Fondos de Solidaridad y Redistribución del Ingreso - FSRI). These funds levy resources from the surplus between the solidarity contributions of the 5th and 6th strata and the commercial and industrial sectors, as well as from the application of subsidies granted to strata 1,2 and 3, which are approved by the SPCs. Strata 4 pays the actual tariff. These resources provide subsidies to other SPCs who, on the contrary, may be in default. In cases in which these resources are still insufficient, they will have access to resources from the relevant state entities or from the national government. The contributions and subsidies are applied to the fixed rate and basic residential consumption block, on which percentage limits are applied by the SPCs and established by the government through its National Development Plan (Plan Nacional de Desarrollo - PND).

Although this has been subject to intense debate, stratification is considered to be a mechanism that concentrates social costs in the face of the existing fiscal restrictions. Some defend it as a low-cost instrument that reflects families' economic strength and that, while not necessarily reflecting families' incomes, does have a relationship with their accumulated incomes over time. Others, on the contrary, consider that it has led to geographic and socio-spatial segregation, which has made social integration more difficult $^{13}$. Moreover, there are obvious limitations in accurately classifying the population into demographics with lesser incomes.

For instance, in 2005 one could already detect unbalance in the subsidy and contributions model as far more resources were granted to strata 1, 2 and 3 than what had been collected from strata 5 and 6 and the commercial and industrial sectors ${ }^{14}$. In fact, almost $80 \%$ of contributions came from commercial and industrial users. Other studies revealed a similar unbalance in the following years (2006-2009) when taking into consideration high transfers on a national level and the signs showing that the existing socio-economic composition did not have enough contributors to cover the totality of subsidies ${ }^{12}$. This explains the change in maximum percentages of contributions and subsidies that occurred throughout time, which shifted the fiscal burden to the higher strata and other sectors (Table 1).

Weaknesses were also detected in the stratification methodology in view of inclusion and exclusion errors as concerns the determination of the population receiving subsidies. It was estimated that about $54 \%$ and $58 \%$ of the population considered to have incomes above the poverty line received water and sanitation subsidies, respectively. It was also found that there were people included in strata 1,2 and 3 whose corresponding income quintile was equivalent with those of strata 4 and $5^{14}$.

This suggests that resolving such inconveniences in subsidy direction would help to ease the existing fiscal burden or to reorient the percentages of subsidies and contributions.

\section{Approximations in determining the basic consumption of water associated with subsidies}

While attention was historically paid mainly to water quality, nowadays quantity is just as considered, as various studies have demonstrated that adequate quantities of water can be more important to control infectious diseases in contaminated atmospheres ${ }^{15}$. According to the World Health Organization (WHO), between 50 and $100 \mathrm{~L} /$ person/day are necessary to satisfy basic needs (consumption and hygiene) and to

Table 1. Maximum percentages of subsidy and contribution on the fixed rate and basic consumption.

\begin{tabular}{lccc}
\hline \multicolumn{1}{c}{ Sector } & $\begin{array}{c}\text { Law 142 } \\
\text { of 1994 }\end{array}$ & $\begin{array}{c}\text { PND } \\
\text { 2003-2006 }\end{array}$ & $\begin{array}{c}\text { PND } \\
\mathbf{2 0 1 0 - 2 0 1 4}\end{array}$ \\
\hline Residential & & & \\
1 & 50 & 70 & 70 \\
2 & 40 & 40 & 40 \\
3 & 15 & 15 & 15 \\
4 & - & - & - \\
5 & 20 & 20 & $50^{*}$ \\
6 & 20 & 20 & $60^{*}$ \\
Commercial & 20 & 20 & $50^{*}$ \\
Industrial & 20 & 20 & $30^{*}$ \\
& & & \\
\hline
\end{tabular}

"Minimum percentage of contribution. 
avoid health risks ${ }^{1}$. Lesser quantities will limit the attainment of other essential development objectives, such as the eradication of poverty and sustainable development ${ }^{16}$.

Accordingly, increasing block tariffs are among those most used today ${ }^{17}$. Whittington ${ }^{18}$ considers that this regime aims to satisfy the principle of equity by establishing affordable prices for an essential amount of water corresponding with the first block, and is based on the premise that the higher one's income is, the higher their consumption will be. Furthermore, it aims to rationalise the use of water through higher prices for consumption levels above the first block, which in turn promotes cross subsidisation between high and low strata ${ }^{17}$.

In accordance with the RPSB, the tariff is composed of a fixed rate, corresponding with the average administration costs, a per unit fee for consumption in increasing blocks, and a connection fee in some cases. The fee for monthly consumption per unit, per household, is classified into blocks of basic (up to $20 \mathrm{~m}^{3}$ ), complementary $\left(20-40 \mathrm{~m}^{3}\right)$ and luxury consumption $\left(40 \mathrm{~m}^{3}\right.$ or more).

The basic consumption block corresponds with the quantity defined as necessary to satisfy a family's basic needs. Thus, the corresponding fee is lesser. Its amount was validated in 1991 through a study that considered measurements of consumption in different hydraulic points in a sample of residences located in five different cities in different regions of Colombia, as well as a survey that aimed to grasp the uses that users considered most important ${ }^{19}$.

While this amount is still applied for the first block in today's tariffs, it is considered that households currently consume lesser amounts for a number of reasons. Firstly, the implementation of the RPSB had the effect of diminishing consumption as it increased tariffs upon readjusting subsidies ${ }^{11}$. Secondly, the methodology used by the Potable Water and Basic Sanitation Regulation Commission (Comisión de Regulación de Agua Potable y Saneamiento Básico - CRA) presented problems in calculating tariffs ${ }^{11}$. Finally, the increased coverage in micro-measurement can also be considered an explanatory factor ${ }^{19}$.

Junca Salas ${ }^{20}$ and Ángel et al. ${ }^{19}$ agreed that it is an acceptable approximation to consider a household's monthly basic consumption to be about $16 \mathrm{~m}^{3}$, which is a well-adjusted amount for the majority of the variations observed in each of the studies' cases. In a more recent analysis (2010), Chacón et al. ${ }^{21}$ demonstrated that the average monthly consumptions of the subsidised strata (1, 2 and 3) vary between about 12 and 16 $\mathrm{m}^{3}$ according to the climate of the examined cities. Relevant literature reports that consumption for the first block varies between 10 and $25 \mathrm{~m}^{3}$ depending on the city ${ }^{17}$.

One of the main arguments against increasing block tariffs is that the limit for basic consumption per subscriber can be below the real basic consumption of a family with many members ${ }^{18}$. Angel et al. ${ }^{19}$ found that the proportion of households whose consumption was in the range of basic consumption had increased through time and was between 75 and $85 \%$ for strata 1 through 4 . Thus, those whose consumption surpassed the basic level could be families with numerous members.

\section{The role of social movements and collective action in access to service}

In Colombia, collective action for the defence of the right to water and sanitation has been motivated by dissatisfaction with respect to the level of access to water, service coverage and quality, tariffs and service privatisation. Mechanisms including mobilisations, protests and civic stoppages have been used in this context.

The country's greatest demonstration of collective mobilisation regarding water was the announcement of the Constitutional Water Referendum. This initiative was the consequence of a period in which several draft bills were being debated, which intended to commercialise natural resources through the sale and concession of environmental services ${ }^{22}$. Many were opposed to the reforms in water and sanitation service provision carried out through Law 142. Arguments included that this service should be considered a public service given the environmental and health-related externalities that it generates, and that private sector participation would not lead to optimal service provision in social terms ${ }^{23}$.

It is thus that between 2005 and 2008, the ECOFONDO Corporation, a non-governmental organisation composed of environmental organisations aiming to promote reflection and political action related to environmental issues, promoted a campaign for water to be treated as a public good.

The campaign attracted participation and support from a significant number of national and international organisations for the defence of water, including the leadership of the National Committee for the Defence of Water and Life (Comité Nacional en Defensa del Agua y de la 
Vida), which was created in this context. In light of the preceding circumstances, in 2007 a call for a popular referendum was made to incorporate a series of articles into the Constitution, including the enshrinement of the fundamental right to potable water and other norms related to this declaration ${ }^{22}$.

Briefly, the referendum's remaining points considered $^{24}$, among others, the responsibility of the State in guaranteeing the protection of water and its declaration as a common and public good and the provision of a minimum essential free volume. At the same point in time, South Africa was supplying a minimum volume of free water in the amount of $6 \mathrm{~m}^{3} /$ month.

In 2008, when draft bill 171 was ratified, the debates within the Congress of the Republic were characterised by differences of opinion and divided interests between political parties and government institutions. In these debates, a substantial modification was proposed concerning the main proposal, whose purpose, among others, was to annul the enshrinement of the human right to water in the Constitution, the definition of water as a common and public good, the provision of a minimum essential amount of free water only to the poor, and the demand that water supply and sanitation services be provided directly and without delegation by the State or organised communities ${ }^{22}$.

Detractors from the proposal argued that the right to water was already recognised in the light of its connection to other rights, that subsidies directed toward the poor already existed, that the minimum essential amount of free water would generate increases in demand and additional expenses, and that service provision managed by municipalities had not proven to be efficient ${ }^{22}$. Finally, in 2010 the proposal was thrown out as it did not receive a sufficient number of votes in Congress.

Unsuccessfully, and in parallel to the referendum, the Office of the Ombudsman (Defensoria del Pueblo) ratified draft bills 197 of 2007 and 047 of 2008, aiming to enshrine and fulfil the Human Right to water.

\section{Inability to pay, service disconnection and protective action}

The human rights framework states that an individual's inability to pay for appropriate water and sanitation services should not be a factor that impedes his/her access to them. Meanwhile, it is recognised that SPCs must be able to collect at least the resources necessary to guarantee oper- ational costs and capital investments for expansion, as well as those related to the replacement of equipment ${ }^{25,26}$. Otherwise systems may become unsustainable, progressively deteriorate, and no longer accomplish their social function. Clearly, when resources are insufficient due to individual's inability to pay, the only manner to guarantee this sustainability is through the participation of public resources external to water and sanitation systems and not exclusively through the full recovery of costs through the fees paid by users ${ }^{8}$.

Paying for this service must not limit one's access to other basic necessities such as health, housing and food. Thus, an efficient tariff model must be considered that can ensure that the poorest pay a lesser tariff to have access to an essential volume of water ${ }^{2}$.

In accordance with Resolution 287 of 2004, during the processes of citizen participation carried out for the establishment of the tariff methodology, the public questioned the fact that the methodology did not take users' ability to pay into account. In this context, the CRA exposed the right that corresponded with the SPCs to recover the costs incurred in providing services, as the legally established subsidies were considered the appropriate tool to contribute to user's ability to pay according to the tariff regime's criteria of solidarity and redistribution.

In accordance with General Observation $n^{\circ}$ 15 , the disconnection of a person's water and sanitation services due to inability to pay constitutes a violation of his/her human right; and these are among the most common violations. It must be taken into account that the disconnection of these services will have repercussions on public health. Consequently, if it is proved that a disconnection occurred due to inability to pay, the user must be reconnected immediately $y^{6}$. Indeed, disconnection should be carried out once the reasons for non-payment are known.

Thus, legal mechanisms should exist to investigate disconnections and seek appropriate remedy. Moreover, they should include processes before, during and after disconnection that will guarantee that a violation of human rights does not occur ${ }^{2,6}$.

Through Sentence T-413/95, the Constitutional Court recognised water as a fundamental human right and reiterated the importance of protecting the rights of individuals, groups and communities in the face of the public authorities' action or lack thereof, including "tutelage measures" (in Colombia, these measures constitutionally guarantee legal protection in the case 
of potential violations of a fundamental rights) or group/popular action.

López-Murcia ${ }^{27}$ discuss the difficulties involved in the process of disconnecting water services in Colombia, due to overlapping responsibilities between the CRA and the Constitutional Court. The RPSB establishes that service provision may be interrupted in the case of non-payment for the period of time determined by the SPC, or in the case of fraud in the physical connections, equipment, meters or pipes. As a result, many disconnected users have recurred to tutelage measures against the SPCs, claiming that their right to a minimum essential quantity of water has been violated and that the Constitutional Court has failed in providing justice to petitioners involved in cases of inability to pay, based on General Observation No. $15^{27}$.

The lack of referential guidelines for disconnection due to non-payment has affected users, who have had to rely on tutelage measures in order to protect their right to water, as well as the SPCs, who do not have directives that cover the topic of disconnection ${ }^{27}$.

Previously, the concept of an essential minimum was recognised by the Constitutional Court through Sentence T-426/92, which established an unnamed right understood to be the guarantee of minimal material conditions to live a decent life. Subsequently, through Sentence T-546/09 the Constitutional Court recognised:

In the Board's estimation, it is not valid to suspend public residential services in all cases of non-payment [...]. If non-payment is involuntary or due to an insurmountable force; if, moreover, the $d$ welling in question is inhabited by persons deserving special constitutional protection; if the service is of an indispensable character to guarantee other fundamental rights such as to life, equality, dignity or health; and if, in conclusion, the conditions established for suspension by law have been met, what must be suspended is the way in which public services are provided. In other words, the fashion in which services are administered must be changed and the final consignee must be given minimum essential and indispensible quantities, in this case, of potable water.

Ultimately, despite the fact that Colombia's previously discussed current tariff structure coincides with the recommendations established by Hoque and Wichelns ${ }^{17}$ in their analyses on tariff structures for this type of service, users are still being disconnected due to their inability to pay.

In the light of this context, an initiative grew from some local governments to consider pro- viding a minimum essential amount of free water to families in conditions of poverty, in respect of the framework for the human right to water and sanitation. The cities pioneering the implementation of this measure were Medellín and Bogotá. In a decentralised and autonomous fashion, each of these cities implemented this plan in accordance with their own criteria. The following section will briefly analyses these experiences.

\section{Implementation of the minimum essential free potable water program in Bogotá and Medellín}

The Medellín City Hall was a pioneer in implementing the free MVAP in Colombia. In 2009 this provision was incorporated into an already existing program denominated Medellín United (Medellin Solidaria), which aims to improve the conditions of families living in situations of extreme poverty. The MVAP was separated from this social program and institutionalised as the MVAP Program through Agreement 06 of 2011. The Program is regulated through Decree 1889 of 2011 and ceased to be a program exclusively applicable to the then-current administrative period (20082011). It was thus converted into a general provision that is independent of the decisions of future administrations, and is currently overseen by the City Hall's Public Services Management Office (Subdirección de Servicios Públicos de la Alcaldía).

In this case, the program benefits individuals subscribed in the Potential Beneficiaries of Social Programs Identification System (Sistema de Identificación de Potenciales Beneficiarios de Programas Sociales - SISBEN). Through a public survey of those in conditions of poverty, the SISBEN performs a classification that local authorities and nation-wide authorities related to social policies use to grant subsidies. The beneficiaries must not surpass the point limit established by Medellín City Hall's administration in accordance with the resources available for subsidies. Furthermore, individuals in situations of displacement may also be beneficiaries.

In Bogotá, on the other hand, the District public policy on water (Accord 347 of 2008) provided the guidelines upon which it was proposed to guarantee a MVAP to residents in conditions of vulnerability and unsatisfied basic needs. Thus, the District Water Plan was adopted through Decree 485 of 2011, which established the conditions to implement the MVAP. These conditions would later be amended and supplemented through Decree 064 of 2012. 
As opposed to Medellín, it was proposed that the program provide the MVAP to strata 1, 2 and 3 in a progressive fashion. However, to date, the program has been implemented for subscribers classified in strata 1 and 2. In the cases of both Medellín and Bogotá, the program has been provided to users by a formal water service provider, and each of the cities' big SPCs - both of which are of a public character - has been notably included in the decision-making processes relative to the programs' implementation.

Chart 1 briefly shows the main differences between both cities in the implementation of this program. In addition, Figure 2 and 3 represent the average number of subscribers and program beneficiaries through time for each case, allowing one to appreciate the contrast of a number of beneficiaries between two types of beneficiary selection models.

Unlike Bogotá, the fact that this provision began as an already established social program in Medellín was a determinant in its adopting an individual characteristic, granting $2.5 \mathrm{~m}^{3} /$ person/ month for free, equivalent with $83 \mathrm{~L} /$ person/day. Bogotá, on the other hand, provides $6 \mathrm{~m}^{3} /$ household/month, based on an estimated average of 4 individuals per family, totalling $50 \mathrm{~L}$ /person/day.
As one may expect, given that this program aims to provide an essential volume of water, these values are inferior to the estimations of a basic volume of water, which was the purpose of the current subsidy, as explained in the previous section. The difference in volumes chosen in each city coincides with the fact that greater volumes should be supplied in Medellín due to the city's climatic conditions.

Each country has the power to define the mechanisms with which they will guarantee access to at least an essential amount of water, as well as the decision of what amount this will be ${ }^{6}$. In the case of both Bogotá and Medellín, these amounts were determined based on recommendations made by the WHO. However, in Bogotá, where this measure is granted per household, there is a risk that this quantity will be less than $50 \mathrm{~L} /$ person/day, which would increase health-related risks.

Another significant difference is that, in Medellín, this discount is not only applied to one's consumption from the water utility, but is applied to sanitation services as well, allowing benefits per person to be greater in the city of Medellín. Thus, in Bogotá this program reaches a greater proportion of the population thanks to

\begin{tabular}{|c|c|c|}
\hline & Bogotá D.C. & Medellín \\
\hline Program Beneficiary & $\begin{array}{l}\text { Subscribers classified in } \\
\text { social strata } 1 \text { and } 2\end{array}$ & $\begin{array}{l}\text { Individuals classified in the SISBEN, who must } \\
\text { not surpass the point limit established by City } \\
\text { Hall's administration, and in displacement } \\
\text { situations }\end{array}$ \\
\hline Essential volume of water & $\begin{array}{l}6 \mathrm{~m}^{3} / \text { household/month }= \\
50 \mathrm{~L} / \text { person/day (4 persons } \\
\text { per household) }\end{array}$ & $2.5 \mathrm{~m}^{3} /$ person $/$ month $=83 \mathrm{~L} /$ person $/$ day \\
\hline Services included in the benefit & Water supply & Water supply and sewerage \\
\hline $\begin{array}{l}\text { Procedure or Mechanism of } \\
\text { access }\end{array}$ & Applied automatically & Request of individuals at the City Hall's facilities \\
\hline $\begin{array}{l}\text { Other benefits related to the } \\
\text { Program }\end{array}$ & - & $\begin{array}{l}\text { Funding campaign for cases in which users are } \\
\text { disconnected due to inability to pay. }\end{array}$ \\
\hline $\begin{array}{l}\text { Average percentage of program } \\
\text { beneficiaries }^{*} \text { (period between } \\
2012-2014 \text { ) }\end{array}$ & $38 \%$ & $4 \%$ \\
\hline
\end{tabular}

* Considering total subscribers and beneficiaries of the main SPCs of each city (Aqueduct and Sewerage Company of Bogotá and Public Services Company of Medellín). 


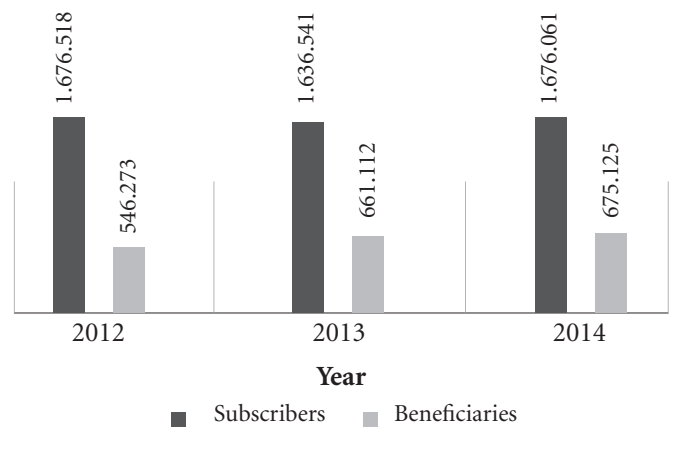

Figure 2. Average number of subscribers and beneficiaries of MVAP in Bogotá.

Source: Data reported on Facilities Information System (http:/ www.sui.gov.co) and provided by the Aqueduct and Sewerage Company of Bogotá.

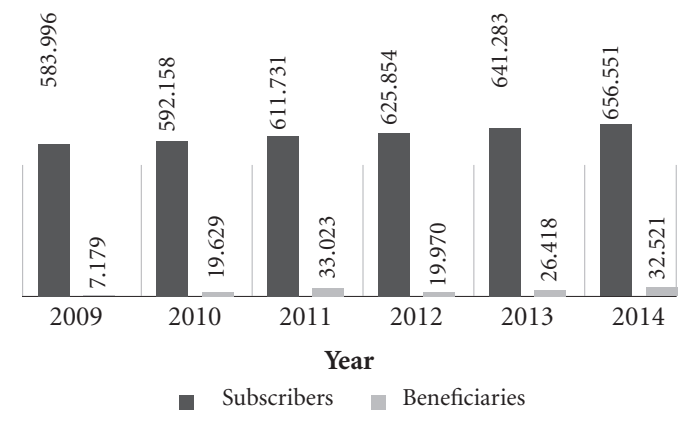

Figure 3. Average number of subscribers and beneficiaries of MVAP in Medellín.

Source: Data reported on Facilities Information System (http:// www.sui.gov.co) and provided for the Medellín City Hall's from Public Services Company of Medellín.

its method of identifying eligible users for applying the benefit. In Medellín, on the other hand, a lesser proportion of the population is sponsored, but beneficiaries receive aid for their water supply and sanitation services, and in greater volumes per individual.

In this regard, each city's decision of their respective method of applying this benefit could have been influenced, among other reasons, by the recognition of the difficulties related to each possible method. In the case of Medellín, while its decision created a resulting demand for more resources for the program's administration and operation, it may have attained a more effective outcome inasmuch as its program exclusively benefits those who really need it. Meanwhile, the decision to use socio-economic stratification in Bogotá may lead to inaccuracies by benefiting those who do not require it. Nevertheless, this method is more practical and demands much less resources to identify beneficiaries, in addition to benefiting a greater proportion of the population.

Moreover, the aid provided in Bogotá is applied directly through the SPC without a requirement for any administrative processes by the user, while individuals desiring assistance in Medellín must make a request at the City Hall's facilities, which can become a limiting factor for the implementation of this benefit. The particularities of Medellín's manner of implementing this model, explained previously, including the fact that it is applied per individual, may lead to an additional administrative burden and, thus, greater $\operatorname{costs}^{28}$.

In accordance with Britto ${ }^{4}$, one of the critiques of social tariff models is their lack of funding or their forgiveness of user debt, as this limits access to these services and thus to the social tariff. In this respect, Medellín created a funding campaign for cases in which users are disconnected due to inability to pay. In this configuration, resources for the MVAP that were unused during the disconnection period are incorporated into the process of funding the debt for the user's reconnection.

The legal foundation of this program was among the main topics evaluated before its implementation. While, on the one hand, the Constitution establishes that municipalities may grant subsidies to society's poorest members to guarantee their ability to pay for the provision of public services that attend to their basic necessities, the RPSB establishes limits to these subsidies which cannot be surpassed in the implementation of this program. Therefore, a sort of social investment program was created and funded through the municipal administration's budget in both cases, which aimed to improve the conditions of certain groups selected in the light of their situation of poverty and vulnerability, and thus of their inability to pay for this service.

Other cities that implemented this program afterwards were Bucaramanga and Cali. In accordance with Decree 215 of 2013, Bucaramanga provides $6 \mathrm{~m}^{3} /$ household/month in Water and Sanitation Services to the households whose 
members are classified in the SISBEN and with priority to the public that is supplied through public water fountains or via communal water meters. Cali provides $6 \mathrm{~m} 3 / \mathrm{subscriber} / \mathrm{month}$ of water for free to social strata 1 and 2 through Accord 370 of 2014. The program has been implemented in other municipalities, applying the conditions that were considered more favourable from cases previously implemented.

Opinions on the pertinence of this program are divided. Some agree that it is a demagogic and inequitable measure, since the program provides free water to people who already receive other subsidies established by law on the premise of fulfilling their human right to water. Moreover, critics point out that the method to identify beneficiaries excludes others in worse conditions.

On this point, in the case of Bogotá, the program has been funded partially through the FSRI $^{29}$. Those funds are contributions from the highest strata (5 and 6), and the commercial and industrial sectors, which could be allocated to other SPCs in case of deficit between contributions and subsidies. This could be understood as an increase in the actual subsidies and contributions established by law in the tariff structure, which was not the purpose of this program.

On the other hand, beneficiaries and followers of this program have expressed their satisfaction, mentioning that savings in payment for service allows them to afford other basic household needs. In this regard, a study of the impact of this program in Bogotá found a decrease in household expenses of $0.21 \%$ and $0.20 \%$ for social strata 1 and 2, respectively, during the period between February 2012 and October $2013^{30}$.

\section{Final considerations}

Independently of the particularities of each city's program, the creation of each case's Program was part of an initiative that sprouted out of the referendum on water, which aimed to enshrine the human right to water in the Constitution and, thus, to provide a minimum essential volume of free water. Collective action was the main protagonist and its achievements were clear. Indeed, although the referendum was not successful in Congress, the proposition in question did interest some municipal governments enough to make them want to pursue its objectives.

In the specific case of a minimum essential volume, the complaints lodged by disconnected users arguing that their human right to water had been violated were undoubtedly decisive. Equally so was the favourable judgment of the Constitutional Court founded on international declarations and justified in the definition of the concept of a vital or essential minimum quantity of which no person can be deprived in the case of inability to pay.

Freely granting service is a prerogative of each particular administration. This decision will mainly need to take into account their financial ability to cover the costs of offering discounts to the given sector of the population selected as potential beneficiaries, as well as the current conditions regarding service provision and the public's socio-economic status. Moreover, it must not be neglected that according to the human rights framework, public resources must prioritise expanding overall coverage with a view to guaranteeing access.

Although this type of program does present the inconvenience of not managing to benefit all those requiring assistance, since it is only those with a connection to a formal service provider that are included, it must be recognised that this policy has positive effects. Indeed, it lessens the economic burden of the beneficiary families, who may now use their resources for other types of necessities. It also provides the benefit of reducing processes of disconnection and reconnection, as well as legal proceedings to dispute people's rights to water.

The application of this program in other municipalities beckons one to consider the establishment of a nation-wide public policy that establishes minimum implementation guidelines. This could avoid some inconveniences, such as those mentioned herein regarding subsidy management before the existence of the RPSB, which puts the efficiency of service provision at risk.

In the two cities analysed in this article, a relevant difference with various implications for the respective programs' implementation was the identification of beneficiaries. In this regard, one may recognise the inclusion- and exclusion-related problems that are typical to implementation models for programs aiming to offer subsidies or other social programs. Thus, studies must be performed that take the circumstances of each case into account in order to guarantee a program's efficiency, including the type of service, the population's socio-economic conditions and the style of funding to be applied ${ }^{8}$.

Moreover, considering the main intention of this policy, its funding must be established clearly for two reasons. Firstly, to avoid that service sub- 
scribers subsidise this benefit through the water tariff. Secondly, to avoid that beneficiaries contribute through any other fees.

In conclusion, despite the influence of the facts exposed herein, it should be noted that the feasibility of this policy is significantly dependent on political considerations. As Swyngedouw ${ }^{31}$ points out in his analysis of the contradictions between the provision of water by public or private service providers, and the collective or social nature of supply services, the decision of granting such benefits is political and is tied to democracy and the distribution of political power.

\section{Collaborations}

L Vargas participated in all research and preparation stages of this article. L Heller participated in the design and critical review of the manuscript.

\section{Acknowledgments}

This article was concluded during the $\mathrm{PhD}$ studies of L Vargas supported by the Exchange Program for Graduate Students PEC-PG of the Brazilian federal research funding agency CAPES. Special thanks are given to Colin Brown for translating the draft of this article from Spanish. 


\section{References}

1. Howard G, Bartram J. Domestic Water Quantity, Service, Level and Health. Geneva: World Health Organization; 2003.

2. De Albuquerque C, Roaf V. On The Right Track. Good Practices in Realising the Rights to Water and Sanitation. Geneva: UN Special Rapporteur on the human right to safe drinking water and sanitation; 2012.

3. Komives K, Halpern J, Foster V, Wodon Q, Abdullah R. Utility subsidies as social transfers: An empirical evaluation of targeting performance. Dev Policy Rev 2007; 25(6):659-679.

4. Britto AL. Tarifas sociais e justiça social no acesso aos serviços de abastecimento de água e esgotamento sanitário no Brasil. In: Castro E, Heller L, Da Piedade Morais M, editors. O Direito À Água Como Política Pública: Uma Exploração Teórica E Empírica. Brasília: Ipea; 2015. p. 209-225.

5. Organisation for Economic Co-operation and Development (OECD). Social Issues in the Provision and Pricing of Water Services. Paris: OECD Publishing; 2003.

6. UN Special Rapporteur on the human right to safe drinking water and sanitation. Realising The Human Rights To Water And Sanitation: A Handbook by the UN Special Rapporteur Catarina De Albuquerque. Geneva: UN; 2014.

7. Fauconnier I. The Privatization of Residential Water Supply and Sanitation Services: Social Equity Issues in the California and International Contexts. Berkeley Plan J 1999; 13(1):37-73.

8. Heller L. Report of the Special Rapporteur on the Human Right to Safe Drinking Water and Sanitation. A/ HRC/30/39. Geneva: Office of the High Commissioner Humans Rights; 2015.

9. Amador Cabra LE. Modelo tarifario, subsidios cruzados y eficencia económica en el sector de saneamiento básico. Con-texto Rev Derecho y Econ 2008; 25:101-132.

10. Perez Pardo C, Uribe Mallarino C, Vasquez Cardoso S. Modelos de provisión de servicios públicos domiciliarios. Una mirada a través del caso de Bogotá. Univ Humanística 2005; 59:64-81.

11. Vélez Gómez LD. Implicaciones tarifarias del servicio de agua potable. Controversia 2008; 191:281-297.

12. Amador Cabra LE. Desbalance fiscal, modelo de subsidios: tendencias, logros y lecciones. Rev Opera 2010; 10:131-147.

13. Uribe-mallarino C. Estratificación social en Bogotá: de la política pública a la dinámica de la segregación social. Univ Humanística 2008; 65:139-171.

14. Colombia. Departamento Nacional de Planeación (DNP). Documento CONPES 3386. Plan de Acción Para La Focalización de Los Subsidios Para Servicios Públicos Domiciliarios. Bogotá: DNP; 2005.

15. Goldblatt M. Realising the right to sufficient water in South Africa's cities. Urban Forum 1997; 8(2):255-276.

16. Chenoweth J. Minimum water requirement for social and economic development. Desalination 2008; 229(13):245-256.

17. Hoque SF, Wichelns D. State-of-the-art review: designing urban water tariffs to recover costs and promote wise use. Int J Water Resour Dev 2013; 29(3):472-491.
18. Whittington D. Possible Adverse Effects of Increasing Block Water Tariffs in Developing Countries. Econ Dev Cult Change 1992; 41:75-87.

19. Ángel J, Rozo J, Hernández L, Valderrama D. Estimación del consumo básico de agua potable en Colombia. Rev Regul - CRA. 2001; 7:15-42.

20. Junca Salas JC. Determinación del consumo básico de agua potable subsidiable en Colombia. Arch Macroecon 2000; 139:1-61.

21. Chacón MG, Lizcano I, Asprilla Y. Consumo básico de agua potable en Colombia. Responsab Soc y Ambient en los Serv públicos 2012; VIII(1):14-23.

22. Gómez Bustos IJ. La acción colectiva del agua en Colombia y el referendo como acercamiento de democracia directa. Análisis Político Doss Ciudad y Confl 2014; 80(enero-abril):79-103.

23. Granados C, Sánchez F. Water Reforms, Decentralization and Child Mortality in Colombia, 1990-2005. World Dev 2014; 53:68-79.

24. Colombia. Registraduría Nacional del Estado Civil República de Colombia. Comunicado de Prensa $N^{\circ} 112$ de 2008. Bogotá: Registraduría Nacional del Estado Civil República de Colombia; 2008.

25. Zetland D, Gasson C. A global survey of urban water tariffs: are they sustainable, efficient and fair? Int $\mathrm{J} \mathrm{Wa-}$ ter Resour Dev 2013; 29(3):327-342.

26. Dalhuisen J. Critical factors for achieving multiple goals with water tariff systems: Combining limited data sources and expert testimony. Water Resour Res 2002; 38(7):7.1-7.11.

27. López-Murcia JD. Regulatory Agencies and Courts in the South: The Overlaps in Colombian Regulation. $J$ Polit Lat Am 2013; 5(2):105-132.

28. Gomez-Lobo A, Contreras D. Water Subsidy Policies: A Comparison of the Chilean and Colombian Schemes. World Bank Econ Rev 2004; 17(3):391-407.

29. Colombia. Superintendencia de Servicios Públicos Domiciliarios. Resumen Ejecutivo Evaluación Integral EAB E.S.P. Bogotá: Superintendencia de Servicios Públicos Domiciliarios; 2015.

30. Herrera C, Rodríguez L. Impacto de La Medida de Mínimo Vital de Agua En La Capacidad de Gasto de Los Hogares Bogotanos Febrero 2012 - Octubre 2013. Bogotá: Cuadernos de Desarrollo Económico; 2015. n 27.

31. Swyngedouw E. Troubled Waters: The Political Economy of Essential Public. In: Castro JE, Heller L, editors. Water and Sanitation Services. Public Policy and Management. London: Routledge; 2009. p. 38-55.

Artigo apresentado em 30/09/2015

Aprovado em 04/12/2015

Versão final apresentada em 17/12/2015 